\title{
8. АНАЛІТИТКА
}

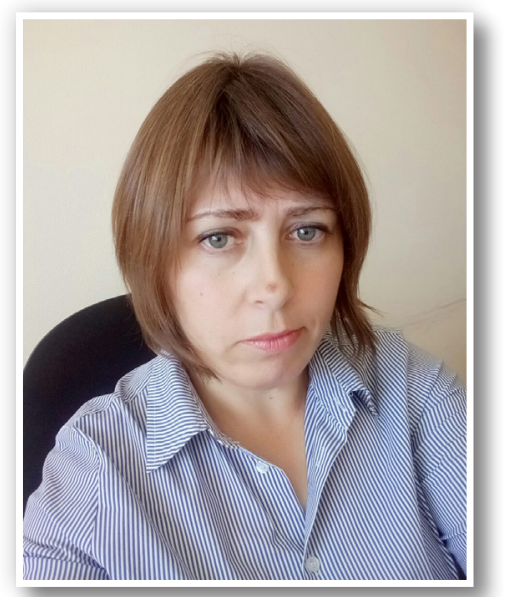

Альона Василівна Малиношевська, кандидат педагогічних наук, заступник директора 3 наукової роботи Інституту обдарованої дитини НАПН України, м. Київ

ORCID://orcid.org/0000-0003-0472-1940

УДК 376-056.45

DOI: https://doi.org/10.32405/2309-3935-2019-3(74)-83-86

\section{ОСОБЛИВОСТІ ОТРИМАННЯ ОСВІТНІХ ПОСЛУГ ДЛЯ ОБДАРОВАНИХ УЧНІВ У ЗАКЛАДАХ ЗАГАЛЬНОЇ СЕРЕДНЬОЇ ОСВІТИ (АНАЛІЗ Б.І. КОРОТЯЄВА)}

Анотація.

У статті запропоновано методи для активізаиії пізнавальної діяльності обдарованих учнів: опис, пояснення, перетворення формулювання ідей. Аргументовано, щз відбір зазначених методів навчання дозволяє активізувати пізнавальну діяльність учнів, сформувати основу до використання складніших дослідних методів. Описано прочедури їх використання. Акцентовано на особливостях використання кожного методу для активізації творчої і самостійної діяльності обдарованих учнів.

Ключові слова: обдарована дитина; пізнавальна діяльність; опис; пояснення; перетворення; формулювання ідеї.

Сьогодні вектор національної політики спрямовано на європейські цінності. Він спонукає забезпечувати відповідний розвиток здібностей кожної дитини, зокрема обдарованої. Серед ефективних умов розвитку обдарувань дитини $є$ наявність поряд творчо обдарованого педагога, який активізує пізнавальну діяльність учня і спонукає до творчих підходів виконання завдань. На наявність взаємозв'язку між пізнавальною та інтелектуальною діяльністю вказували такі видатні вчені, як С. Рубінштейн, С. Костюк, Дж. Рензуллі та ін. Так, С. Рубінштейн зазначав, що зростання рівня розвитку мислення учня розширює водночас можливості засвоєння ним знань. Збільшення кількості знань спонукає до подальшого розвитку мислення.

Пізнавальна діяльність учнів активізується вчителем. Науковці відзначають складові пізнавальної активності: мотиваційна (потреба в пізнанні, прагнення до самовдосконалення); психічні якості (емоційне сприйняття, творча уява, мислення, мовленнєва компетентність); інструментальні (форми, методи, технологіiі) [1].

Пізнавальна діяльність здійснюється під керівництвом учителя і корегується ним у процесі надання освітніх послуг. Водночас можливість учнівської творчості попередньо прогнозується вчителем у процесі підготовки до заняття. Учитель має поєднувати пізнавальну діяльність учнів (особливо обдарованих)
3 підготовкою їх до використання наукових методів. Маючи такі наміри учитель має враховувати не лише потреби, а й вікові особливості та можливості учнів, їхню підготовку та специфіку предмета. Сьогодні вже не виникає сумніву в необхідності використанні наукового підходу в освітній діяльності. Які ж методи наукового підходу до пізнання $є$ оптимальними до розуміння та використання учнями? Відбір їх, перш за все, зумовлено завданнями, що виникають перед учнями у процесі засвоєння теоретичного матеріалу: розпізнати явище (об'єкт), його ознаки, складники, зв'язки і відношення, алгоритми перетворення; описати його, пояснити причини чи способи існування, сформулювати правило його перетворення. Розв'язання цих задач потребує використання певних методів пізнання:

1) виділення сутнісних, достатніх та необхідних ознак і властивостей, що містяться на поверхні та не потребують доказів за допомогою спостереження, перетворення (аналізу) та їх роз'єднання на певні складники (синтез), протиставлення, відчленування тощо;

2) визначення закономірних зв'язків за допомогою спостереження, перетворення, схем, ідей і принципів, дедукиї̈, індукції, абстрактного до конкретного тощо;

3) виявлення правил та алгоритмів перетворення явищ за допомогою спостереження та знаходження ключа алгоритму. 
Щодо другої задачі, то з метою розвитку та поглиблення знань використовуються:

1) методи опису розпізнаних ознак явищ за допомогою обгрунтувань (згорнутих описів) та оповідей (розгорнутих описів);

2) методи пояснення розпізнаних зв'язків за допомогою формулювання тверджень, законів, тез, принципів, теорем, формул, що розкривають зв'язки та відносини, а також обгрунтування і доказовості закономірності характеру тощо;

3) методи виведення пропозицій за допомогою правил, алгоритмів та їх застосування на практиці за будьяких способів, у тому числі за зразком, аналогією тощо.

Отже, в основі творчої пізнавальної діяльності згадані методи застосовуються учнем на етапі формулювання теоретичних знань і мають певні сфери використання: опис, пояснення та використання на практиці. Учень фіксує отриману інформацію у свідомості, а потім має можливість за необхідних умов іiі запровадити на практиці. Обдарований учень систематизує отримані знання під час їх засвоєння, порівнює їх з певним еталоном. В основі репродуктивної (нетворчої) діяльності міститься лише один варіант, точне виконання якого завжди призводить до заданого результату.

Звернімо увагу на те: чи будь-яка інформація, яку отримує учень, піддається прогнозуванню? На це запитання можемо дати лише одну відповідь: ні, не будь-яка. Піддається прогнозуванню лише та наукова інформація яку отримує учень, що має логічну послідовність та відображає зв'язки, між явищами і процесами, прийомами їх виявлення.
3 огляду на це, склалися відповідні проиедури пізнання, а саме: розпізнавання, описання, пояснення, перетворення. Кожна з них здійснюється за межами видимого та містить сукупність чітко визначених операцій, що можуть бути: мисленнєвими, предметними (з певними предметами), мовно-логічними. Розглянемо кожний із варіантів згаданих процедур.

Метод опису дає змогу зафіксувати певними засобами суттєві ознаки об'єкта чи явища вивчення або результатів спостереження, вимірювання, порівняння, експерименту. Пропонуємо ознайомитися 3 процедурою використання методу опису, який широко використовують в науці, на практиці, побуті. В освітній діяльності учнів опис використовувався і раніше. Вміння використовувати процедуру опису дозволяє учню, з одного боку, раціонально та економно сприймати, засвоювати, перетворювати та озвучувати інформацію з різних джерел, а 3 іншого самостійно і творчо описувати різні явища.

Учень, володіючи набором відповідних понять і використовуючи процедуру опису, може не лише засвоювати значні об'єми інформації, а й розвивати власні творчі здібності.

Процедура опису може мати дві функції: упорядкування та орієнтування. Процедура описання має дві форми: згорнуту та розгорнуту. Перша форма опису використовується в таких науках, як математика, фізика, хімія, мова, креслення, а друга - в історії, природознавстві, літературі, біології, географії.

Схематично процедуру опису можна представити таким чином (табл. 1).

Процедура згорнутого та розгорнутого опису

\begin{tabular}{|c|c|c|c|c|c|}
\hline № & $\begin{array}{c}\text { Опис явища } \\
\text { (об'скти) }\end{array}$ & $\begin{array}{c}\text { Указусться } \\
\text { родова ознака } \\
\text { (Перша операція) }\end{array}$ & $\begin{array}{c}\text { Указується } \\
\text { видова ознака } \\
\text { (Друга операція) }\end{array}$ & $\begin{array}{c}\text { Формулюється } \\
\text { визначення } \\
\text { (Третя операція) }\end{array}$ & $\begin{array}{c}\text { Указуються } \\
\text { додаткові ознаки } \\
\text { і формулюється } \\
\text { розповідь }\end{array}$ \\
\hline 1 & 2 & 3 & 4 & 5 & 6 \\
\hline & & & & & \\
\hline
\end{tabular}

Заповнення таблиці 1 згорнутим описом можливо більшістю математичних об'єктів, частину фізичних i хімічних явищ, історичних, соціально-економічних та інших процесів. При чому виокремлено мовно-логічні операції залишаться незмінними, а зміниться лише мова опису. Розгорнутий опис виконує ті ж функції, але відрізняється від попереднього більш рухливим і менш стандартизованим. Він передбачає конструювання множини логічно, семантично та синтаксично пов'язаних між собою речень, що послідовно відображають особливості, властивості, побудову предмету, хід події, процесу.

Аналогічно можна описувати більшість об'єктів та явищ різних наук.

Таким чином, процедура опису містить три системи:

- периа - операції, що створюють систему згорнутого опису;

- друга - операції, що створюють систему розгор-
- mpem - операції, що створюють систему умовнознакового опису.

У цих трьох зазначених системах, перш ніж виконувати відповідні операції, необхідно виконати перцептивні, мисленнєві та інші операції, а саме: спостереження, порівняння, аналіз, синтез тощо, що пов' язано $з$ пошуком та виявленням ознак і властивостей предметів та явищ.

Метод пояснення надає можливість розкрити сутність певного предмета чи явища, закону, процесу. Пропонуємо ознайомитися з процедурою пояснення, що використовується в побуті, відрізняється від попередньої процедури тим, що в іiі складі відсутня ланка обтрунтування і доказовості. Іноді будується з порушенням законів і правил діалектичної і формальної логіки. Разом $з$ тим, наукове пояснення має грунтуватися на законах і правилах з виконанням необхідних і визначених операціях (наприклад, мисленнєвих, перцептивних, предметних і словесно-логічних). 
Використання в пізнавальній діяльність учня процедури пояснення дає змогу глибоко і грунтовано засвоювати готову інформацію й самостійно пояснювати явища, що підлягають вивченню. Наприклад, з'ясувавши залежність між поняттями «діаметр», «хорда», «дуга», «відрізок», «перпендикуляр» вони самостійно мають сформулювати два речення, щоб відобразити цю залежність: «Діаметр перпендикулярний хорді і ділить хорду і дуги, що іï стягують пополам» і навпаки. Сформулювавши цю теорему учні зможуть їі довести. Процедура пояснення можна використовувати не лише в процесі вивчення математики, а й під час вивчення фізики, хімії, біології, історії, мови та літератури. Використовуючи процедуру пояснення через встановлення зв'язків і відносин необхідно: по-перше, не лише спостерігати за явищем, а й, якщо можливо, спробувати виконати певні перетворювання; по-друге, володіти достатньою кількістю понять 3 теми.

Одним зі способів пояснення явища $\epsilon$ спосіб виявлення необхідних умов та обставин його створення та існування. Процедура пояснення можлива розгортатися таким чином:

Спостереження явища $\rightarrow$ можливі пробні перетворення $\rightarrow$ виявлення умов утворення та існування $\rightarrow$ формулювання пропозицій, що відображають ці умови $\rightarrow$ обгрунтування (доказовість) того, що виявлені умови породжують утворення та існування явищ.

Для виконання процедури пояснення способом виявлення умов та обставин існування явища необхідно також мати: а) задані умови; б) набір описаних та пояснених понять.

Процедура перетворення. Ця процедура відрізняється від попередніх наявністю специфічних операцій.

У процедурі перетворення використовуються такі операції: спостереження і пробні перетворення явища; знаходження та формулювання правил перетворення; їх обтрунтування та застосування. Розглянемо їх на прикладі $з$ математики. Нехай потрібно виконати додавання дробів $з$ однаковими знаменниками: $2 / 7+3 / 7$. Для його розв'язання потрібно вивести правило. Для учнів можна запропонувати приклад виведення необхідного правила на частинах цілого. Наприклад, взяти яблуко, розрізати на сім рівних частини і до двох частинок додати три частинки, але самі частинки не змінюються: $2 / 7+3 / 7=5 / 7$.

Зазначені дії дозволяють учню вивести загальне правило: у процесі додавання дробів 3 однаковими знаменниками необхідно додати чисельники і результат записати в чисельнику, а знаменник залишається без зміни.

Для формулювання правил необхідно мати: задані умови; можливість виконання пробних перетворень; достатній набір понять для опису операції, з допомогою якої здійснюється перетворення.

Отже, операція перетворення відрізняється для математико-природничих і гуманітарних наук. В останній процедура перетворення може містити уза- гальнений характер та описувати швидше перспективу розвитку чи виходити на формулювання ідеї. Тому процедура виходу на формулювання ідеї $\epsilon$ найвищим рівнем творчої та пізнавальної діяльності, що притаманна швидше інтелектуально обдарованим учням. Решта учнів може виходити на неї з аналогу - формулювання ідеї, що належить базовій теорії та переносить вихідну теорію з однісї теорії в іншу. Однак, якщо йдеться про вихідні ідеї, то процедура виходу на них і попереднього згортання спостереження спрощується і може мати такий вигляд:

перша операція - формулювання ідеї за прикладом чи аналогією;

друга операція - формулювання пропозицій, що стисло розкривають загальну ідею, аналогічно до базової;

третя операція - формулювання пропозицій, які розкривають змістовий смисл ідеї;

четверта операція - побудова короткої розповіді 3 використанням прикладів, фактів, ілюстрацій.

Для успішного навчання учнів 3 використанням описаних наукових методів необхідно враховувати, що на початковому етапі вивчення теми переважає описовий матеріал, а на наступних - матеріал для пояснення і встановлення зв'язків. Під час вивчення таких дисциплін, як математика, фізика, хімія, для пояснення використовується понятійна мова і мова формул. Під час вивчення мови - понятійна мова, а літератури - понятійна і художньо-образна. На історії, географії, біології використовується понятійна і знакова мова. Щоб учні могли самостійно описати певний об'єкт або явище і правильно виконати всі послідовні операції з ним необхідно:

1) чітко сформулювати завдання опису з визначенням його меж - згорнуте або розгорнуте;

2) запропонувати об'єкт для спостереження справжній чи модель, схему, зображення; якщо вивчається явище, то дати загальну картину його протікання - словесно, з допомогою мапи, малюнка, схеми;

3) дати раніше вивчені опорні поняття, а також зазначити необхідні елементи для опису предмета чи явища - назва об'єкта, його складники, терміни, умовні позначення тощо;

4) визначити межі й орієнтири для самостійного розпізнавання сутнісних ознак схожості та різниці; якщо необхідно подати підказку - де, а саме як, які ознаки шукати.

Для підготовки ж учнів до виконання завдань на пояснення зв'язків між об'єктами чи явищами учителю потрібно:

- чітко сформулювати завдання;

- вказати орієнтири для розпізнавання зв'язків i відношень між структурними компонентами об'єкта чи явища;

- якщо потрібно, то вказати на характер зв'язків;

- показати можливі варіанти логічної побудови речень, що відображають встановлені зв'язки й відносини; 
- показати характерні варіанти обгрунтування запропонованих рішень, ідей, що використовуються в процесі доведення;

- надати перелік опорних понять і аксіом, які можна використовувати під час доведення.

Таким чином, нами здійснено аналіз розвитку творчої діяльності учнів за Б. Коротяєвим. У подальших розвідках ми будемо пропонувати інші технологічні доробки освітян щодо вдосконалення пізнавальної освітньої діяльності учнів школи.

\section{Використані літературні джерела}

1. Гевко $O$. Активізація навчально-пізнавальної діяльності учнів на уроках у загальноосвітній школі / О. Гевко // Людинознавчі студії. Вип. 29., 2014. Ч. 2. С. 50-57. (Серія «Педагогіка»). URL: http://dspu.edu.ua/pedagogics/arhiv/29_ ch2_2014/8.pdf.

2. Коротяев Б.И. Учение процес творческий: Кн. для учителя: Из опыта работы / Б.И. Коротяев. 2-е изд., доп. и испр. Москва: Просвещение, 1989. 159 с.

\section{References}

1. Hevko, O. (2014). Aktyvizatsiya navchal'no-piznaval'noyi diyal'nosti uchniv na urokakh u zahal'noosvitniy shkoli [Activation of educational and cognitive activity of students at lessons in a comprehensive school]. Lyudynoznavchi studiyi - Human studies. Vol. 29. p. 50-57. Retrieved from: http://dspu.edu.ua/ pedagogics/arhiv/29_ch2_2014/8.pdf.

2. Korotyaev, B.Y. (1989). Uchenye protses tvorcheskyy [The teaching process is creative]. Moscow, $159 \mathrm{p}$.

Malynoshevskaya Alena. Features of Educational Services for Gifted Students in High School (Analysis by B. I. Korotyaev).

Summary.

The article proposes methods for activating the cognitive activity of gifted students: description, explanation, transformation of the formulation of ideas. It is argued that the selection of these teaching methods allows to activate the cognitive activity of students, to form the basis for the use of more sophisticated research methods. Procedures for their use are described. Emphasis is placed on the peculiarities of using each method to activate the creative and independent activity of gifted students. It is noted that the description procedure can have two functions: ordering and orientation. The description procedure has two forms: collapsed and expanded. The first form of description is used in the sciences such as: mathematics, physics, chemistry, language, drawing, and the second in history, science, literature, biology, geography. The use of explanatory procedures in the cognitive activity of the student allows to thoroughly and thoroughly absorb ready information and independently explain the phenomena being studied. The following operations are used in the conversion procedure: observation and trial transformation of the phenomenon; finding and formulating conversion rules; their justification and application. Successful student learning using the described scientific methods should take into account that descriptive material prevails at the initial stage of studying the subject, and explanatory and communication material prevails in the following. In the study of disciplines such as mathematics, physics, chemistry, conceptual language and formula language are used to explain it. In the study of languageconceptual language, and literature - conceptual and artistic. History, geography and biology use conceptual and sign language.

Key words: gifted child; cognitive activity; description; explanation; transformation; formulation of an idea.

Малиношевская А.В. Особенности образовательных услуг одаренными учащимися у средней школе (анализ Б. Коротяева).

Аннотация.

B статье предложены методы для активизащии познавательной деятельности учашихся: описание, объяснение, формулировка идей. Описаны процедуры их использования. Акиентировано на особенностях использования каждого метода для активизащии творческой и самостоятельной деятельности одаренных учеников.

Ключевые слова: одаренный ребенок; познавательная деятельность; описание, объяснение; преобразование; формулировка идеи. 